\title{
Article \\ Characterization and Toxicity of Crude Toxins Produced by Cordyceps fumosorosea against Bemisia tabaci (Gennadius) and Aphis craccivora (Koch)
}

\author{
Jianhui Wu ${ }^{1,2,+}$, Bo Yang ${ }^{1,2,+}$, Jing $X u^{1,2}$, Andrew G. S. Cuthbertson ${ }^{3}$ and Shaukat Ali ${ }^{1,2, *}$ \\ 1 Key Laboratory of Bio-Pesticide Innovation and Application, Guangzhou 510642, China; \\ jhw@scau.edu.cn (J.W.); yb@stu.scau.edu.cn (B.Y.); zhibaoxujing@stu.scau.edu.cn (J.X.) \\ 2 Engineering Research Center of Biological Control, Ministry of Education and Guangdong Province, South \\ China Agricultural University, Guangzhou 510642, China \\ 3 Independent Science Advisor, York YO10 5AQ, UK; andrew_cuthbertson@live.co.uk \\ * Correspondence: aliscau@scau.edu.cn \\ + These authors contributed equally to this work.
}

Citation: Wu, J.; Yang, B.; Xu, J.; Cuthbertson, A.G.S.; Ali, S. Characterization and Toxicity of Crude Toxins Produced by Cordyceps fumosorosea against Bemisia tabaci (Gennadius) and Aphis craccivora (Koch). Toxins 2021, 13, 220. https:// doi.org/10.3390/toxins 13030220

Received: 10 February 2021

Accepted: 15 March 2021

Published: 18 March 2021

Publisher's Note: MDPI stays neutral with regard to jurisdictional claims in published maps and institutional affiliations.

Copyright: (c) 2021 by the authors. Licensee MDPI, Basel, Switzerland. This article is an open access article distributed under the terms and conditions of the Creative Commons Attribution (CC BY) license (https:// creativecommons.org/licenses/by/ $4.0 /)$.

\begin{abstract}
Cordyceps fumosorosea, an insect pathogenic fungus, produces different toxins/secondary metabolites which can act as pest control agents. This study reports the extraction and characterization of crude mycelial extracts of C. fumosorosea isolate SP502 along with their bio-efficacy against Bemisia tabaci and Aphis craccivora. Fourier transform infrared spectroscopy, liquid chromatography, mass spectrometery and nuclear magnetic resonance analysis of C. fumosorosea isolate SP502 extracts showed the presence of five major compounds-Trichodermin, 5-Methylmellein, Brevianamide F, Enniatin and Beauvericin - which all may potentially be involved in insecticidal activity. The HPLC analysis of $C$. fumosorosea mycelial extracts and Beauvericin standard showed similar chromatographic peaks, with the content of Beauvericin in the crude toxin being calculated as $0.66 \mathrm{mg} / \mathrm{ml}$. The median lethal concentrations of $C$. fumosorosea mycelial extracts towards first, second, third and fourth instar nymphs of $A$. craccivora were $46.35,54.55,68.94$, and $81.92 \mu \mathrm{g} / \mathrm{mL}$, respectively. The median lethal concentrations of $C$. fumosorosea mycelial extracts towards first, second, third and fourth instar nymphs of B. tabaci were $62.67,72.84,77.40$, and $94.40 \mu \mathrm{g} / \mathrm{mL}$, respectively. Our results demonstrate that bioactive compounds produced by $C$. fumosorosea isolate SP502 have insecticidal properties and could, therefore, be developed into biopesticides for the management of B. tabaci and A. craccivora.
\end{abstract}

Keywords: biological control; Cordyceps fumosorosea-SP502; toxin; whitefly; aphids; toxicity

Key Contribution: This study reports the extraction and characterisation of crude mycelial extracts of C. fumosorosea isolate SP502 along with their bio-efficacy against Bemisia tabaci and Aphis craccivora.

\section{Introduction}

Bemisia tabaci Gennadius (Hemiptera: Aleyrodidae), a species complex containing 36 or more cryptic species, continues to be a major threat to field crop production across the globe [1,2]. Population levels and infestation by B. tabaci Middle East-Asia Minor 1 (MEAM1) (previously known as "Biotype B") is by far the most common. It is the most notoriously invasive species of the Bemisia species complex, having increased greatly during the last twenty years [3,4]. Bemisia tabaci MEAM1 damages plants directly through feeding on cell sap, and indirectly by honey dew secretion which leads to sooty mould growth on plant surfaces [5]. In addition, B. tabaci MEAM1 is also a vector of over 150 viral crop diseases [6].

Aphis craccivora Koch (Homoptera: Aphididae), also known as cowpea aphid, is a major pest of cowpea and other crops in different regions of the world [7]. Both nymphs and adults can damage the crops. Aphis craccivora causes economic damage either by 
directly sucking the sap from aerial plant parts or by releasing honeydew on plant leaves which leads to sooty mould production [8]. The severe damage of A. craccivora can cause delayed flowering and yield a loss of more than 50\% [9]. In addition, they are also a vector of many viral plant diseases [10].

Insect pest management has generally been achieved using synthetic agro-chemicals. However, their overuse has resulted in the development of insecticide resistance by many insect pests $[11,12]$. In addition, the negative impacts of synthetic insecticides on beneficial insects $[13,14]$ and humans have forced the agricultural industry to seek the development of bio-rational and natural/indigenous methods to control insect pests [15]. Therefore, the development and application of biochemicals/biopesticides originating from naturally occurring insect pathogenic fungi can potentially provide an alternative to synthetic insecticides [16].

Entomopathogenic fungi have been suggested as potential agents for the biological control of different insects for over a century. Diversified species range, complex metabolic types, and appropriate safety levels for humans and other non-target organisms of entomopathogenic fungi makes them more attractive than other pest control tactics [15]. Cordyceps fumosorosea (previously known as Isaria fumosorosea) is a well-documented entomopathogen used for insect pest management [17]. Different isolates of C. fumosorosea have been effective against aphids, scales, whiteflies and other insect pests across the globe [17-21]. Cordyceps fumosorosea produces different secondary compounds/toxins such as Beauvericin, Beauverolides and 2,6-pyridindicarboxylic acid (also known as dipicolinic acid; DPA) [22-25] which may be effective in the control of insect pests.

The aims of the current study were to (i) extract and characterise the mycelial extracts/secondary chemicals of $C$. fumosorosea isolate SP502 which has shown considerable pathogenicity against $B$. tabaci in our previous studies [26]; (ii) undertake toxicity assays of mycelial extracts/secondary chemicals against nymphal instars of B. tabaci and A. craccivora.

\section{Results}

\subsection{Fourier Transformed Infrared Spectroscopy (FTIR)}

FTIR analysis was performed to find the functional groups of the active compounds based on the peak value in the infrared region (Figure 1 and Table 1). FTIR analysis showed the presence of prominent bands due to the $\mathrm{O}-\mathrm{H}$ stretch alcohols or phenols $\left(3458.89 \mathrm{~cm}^{-1}\right)$, $\mathrm{N}-\mathrm{H}$ alkane (Methyl) $\left(2970.68 \mathrm{~cm}^{-1}\right), \mathrm{C}-\mathrm{H}$ alkane (Methylene) $\left(2928.95 \mathrm{~cm}^{-1}\right), \mathrm{C} \equiv \mathrm{C}$ stretch nitrile $\left(2015.74 \mathrm{~cm}^{-1}\right), \mathrm{C}=\mathrm{O}$ carboxylic acid $\left(1729.67 \mathrm{~cm}^{-1}\right), \mathrm{C}=\mathrm{C}$ stretch alkane $\left(1516.99 \mathrm{~cm}^{-1}\right), \mathrm{C}=\mathrm{O}$ trans-alkenes $\left(1454.26 \mathrm{~cm}^{-1}\right), \mathrm{C}=\mathrm{C}$ trans-alkenes $\left(1373.96 \mathrm{~cm}^{-1}\right), \mathrm{C}=\mathrm{C}$ trans-alkenes $\left(1344.48 \mathrm{~cm}^{-1}\right), \mathrm{C}=\mathrm{C}$ ester carbonyl group $\left(1295.41 \mathrm{~cm}^{-1}\right), \mathrm{C}=\mathrm{C}$ ether/alcohol $\left(1104.42 \mathrm{~cm}^{-1}\right), \mathrm{C}-\mathrm{O}$ trans-alkenes $\left(1013.50 \mathrm{~cm}^{-1}\right), \mathrm{C}=\mathrm{C}$ vinyl-alkenes $\left(928.39 \mathrm{~cm}^{-1}\right), \mathrm{C}=\mathrm{C}$ aromatics $\left(866.68 ; 744.30 \mathrm{~cm}^{-1}\right)$, and aromatics (Ring) $\left(525.81 \mathrm{~cm}^{-1}\right)$. 


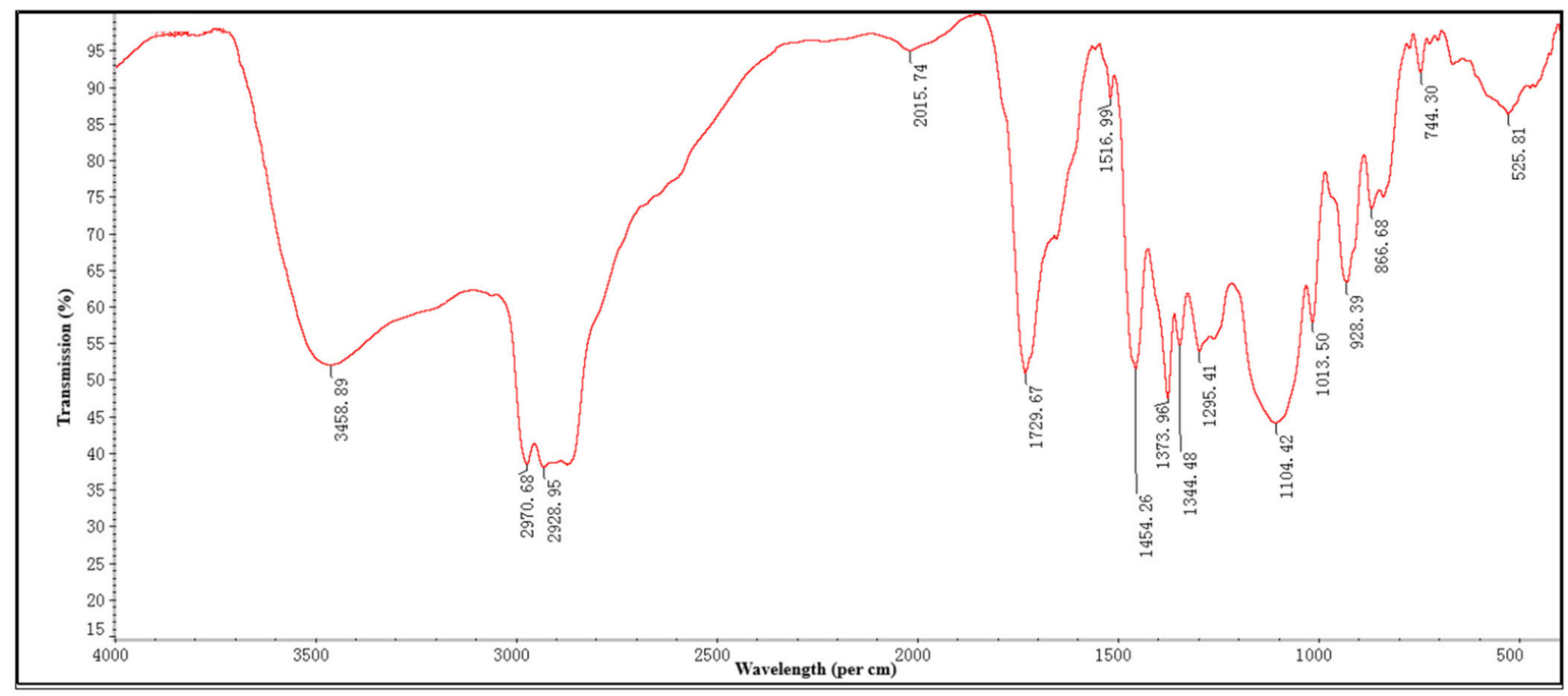

Figure 1. FTIR analysis of the ethyl acetate mycelia extract obtained from Cordyceps fumosorosea.

Table 1. FTIR spectrum of ethyl acetate extract obtained from Cordyceps fumosorosea.

\begin{tabular}{ccc}
$\begin{array}{c}\text { Observed Wave Numbers } \\
\left(\mathbf{c m}^{-\mathbf{1})}\right.\end{array}$ & Functional Group & Bonding Pattern \\
\hline 3458.89 & O-H stretch alcohols or phenols & Strong, broad \\
2970.68 & N-H alkane (Methyl) & Sharp \\
2928.95 & C-H alkane (Methylene) & Strong, medium \\
2015.74 & C $\equiv$ C stretch nitrile & Weak \\
1729.67 & C=O carboxylic acid & Strong, sharp \\
1516.99 & C=C stretch alkane & Weak, sharp \\
1454.26 & C=O trans alkenes & Strong, sharp \\
1373.96 & $\mathrm{C}=\mathrm{C}$ trans alkenes & Strong, sharp \\
1344.48 & $\mathrm{C}=\mathrm{C}$ trans alkenes & Weak, sharp \\
1295.41 & $\mathrm{C}=\mathrm{C}$ ester carbonyl group & Weak, medium \\
1104.42 & $\mathrm{C}=\mathrm{C}$ ether/alcohol & Strong, medium \\
1013.50 & $\mathrm{C}-\mathrm{O}$ trans-alkenes & Strong, sharp \\
928.39 & $\mathrm{C}=\mathrm{C}$ vinyl-alkenes & Strong, sharp \\
866.68 & $\mathrm{C}=\mathrm{C}$ aromatics & Strong, medium \\
744.30 & $\mathrm{C}=\mathrm{C}$ aromatics (Ring) & Weak, sharp \\
525.81 & $\mathrm{C}=\mathrm{C}$ Aromatics (Ring) & Weak, sharp \\
\hline
\end{tabular}

\subsection{Liquid Chromatography-Mass Spectrometry Analysis of Cordyceps fumosorosea}

The LC-MS results obtained from the ethyl acetate extract of SP502 indicated the presence of five main fractions: Trichodermin $\left(\mathrm{C}_{17} \mathrm{H}_{24} \mathrm{O}_{4}\right.$; retention time: 0.340), 5-Methylmellein $\left(\mathrm{C}_{11} \mathrm{H}_{13} \mathrm{O}_{3}\right.$; retention time: 0.344), Brevianamide $\mathrm{F}\left(\mathrm{C}_{16} \mathrm{H}_{17} \mathrm{~N}_{3} \mathrm{O}_{2}\right.$; retention time: 2.0621$)$, Enniatin $\left(\mathrm{C}_{32} \mathrm{H}_{55} \mathrm{~N}_{3} \mathrm{O}_{9}\right.$; retention time: 2.565$)$ and Beauvericin $\left(\mathrm{C}_{45} \mathrm{H}_{57} \mathrm{~N}_{3} \mathrm{O}_{9}\right.$; retention time: 9.615) which may potentially be involved in insecticidal activity (Figure 2 and Table 2). 
Table 2. LC-MS spectrum of ethyl acetate extract obtained from Cordyceps fumosorosea.

\begin{tabular}{ccccc}
\hline Sr\# & Compound Name & Rt & Molecular Formula & Biological Activity \\
\hline 1 & Trichodermin & 0.340 & $\mathrm{C}_{17} \mathrm{H}_{24} \mathrm{O}_{4}$ & Fungicide; Pesticide \\
2 & 5-Methylmellein & 0.344 & $\mathrm{C}_{11} \mathrm{H}_{13} \mathrm{O}_{3}$ & Antimicrobial activity \\
3 & Brevianamide F & 2.062 & $\mathrm{C}_{16} \mathrm{H}_{17} \mathrm{~N}_{3} \mathrm{O}_{2}$ & Antioxidant activity, mycotoxin \\
4 & Enniatin & 2.565 & $\mathrm{C}_{32} \mathrm{H}_{55} \mathrm{~N}_{3} \mathrm{O}_{9}$ & Antimicrobial activity \\
5 & Beauvericin & 9.615 & $\mathrm{C}_{45} \mathrm{H}_{57} \mathrm{~N}_{3} \mathrm{O}_{9}$ & Mycotoxin \\
\hline
\end{tabular}
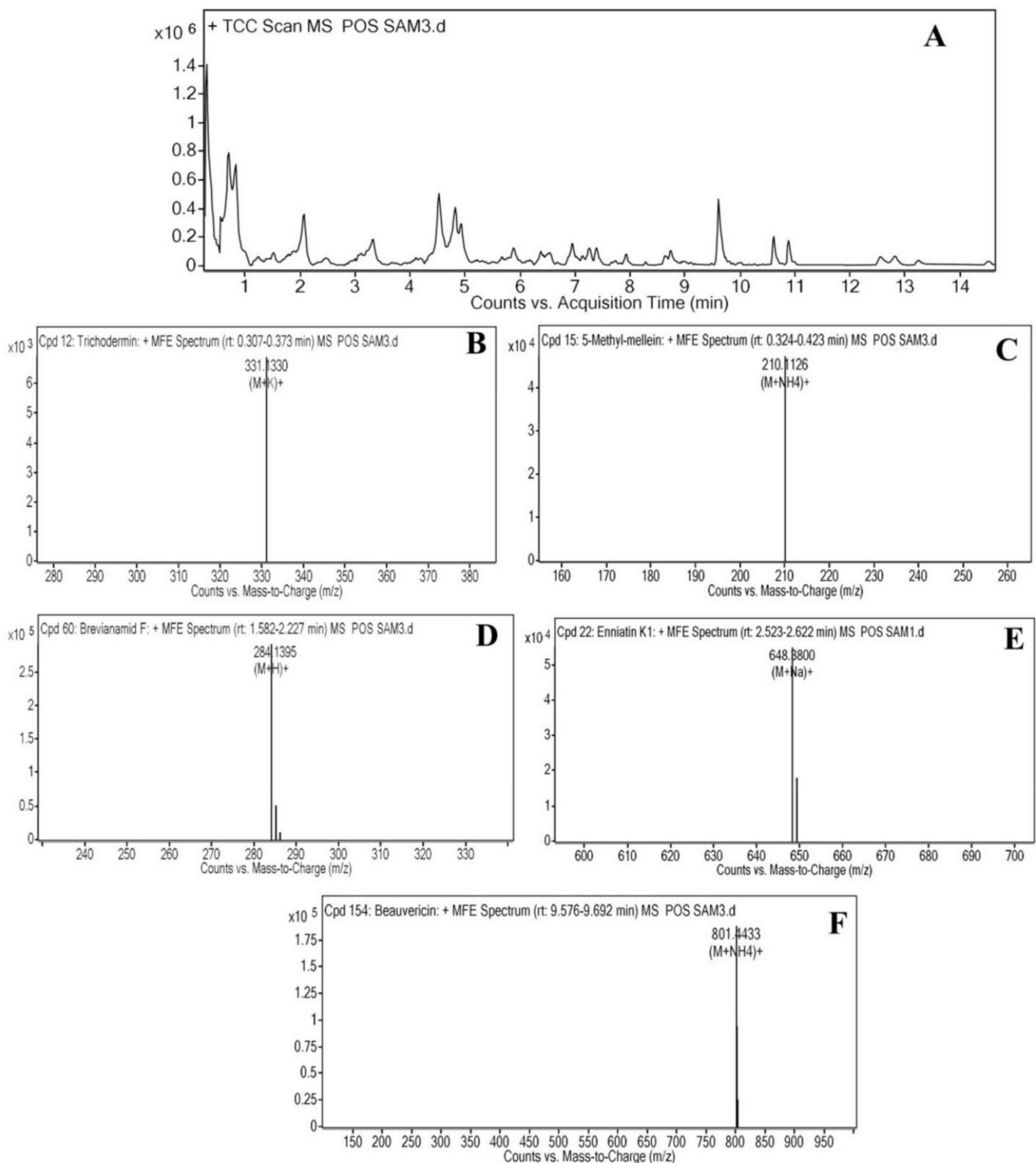

Figure 2. LC-Ms analysis of bioactive compounds produced by Cordyceps fumosorosea isolate SP502. (A) LC-MS profile; (B) Trichodermin; (C) 5-Methylmellein; (D) Brevianamide F; (E) Enniatin; (F) Beauvericin. 


\subsection{Nuclear Magnetic Resonance (NMR)}

The ${ }^{1} \mathrm{H}$ NMR analysis of metabolic compounds produced by C. fumosorosea isolate SP502 shows a high resonance band in aliphatic (0.9-1.4 ppm), allylic, pyrrolidine ring and $\mathrm{NeCH}$ (2.0-2.6 ppm and 2.1-3.5 ppm), an ether linkage (3.5-4.3 ppm), and amide proton $(7.3-7.8 \mathrm{ppm})$ regions. These findings further confirm the production of metabolic compounds detected through LC-MS analysis (Figure 3).

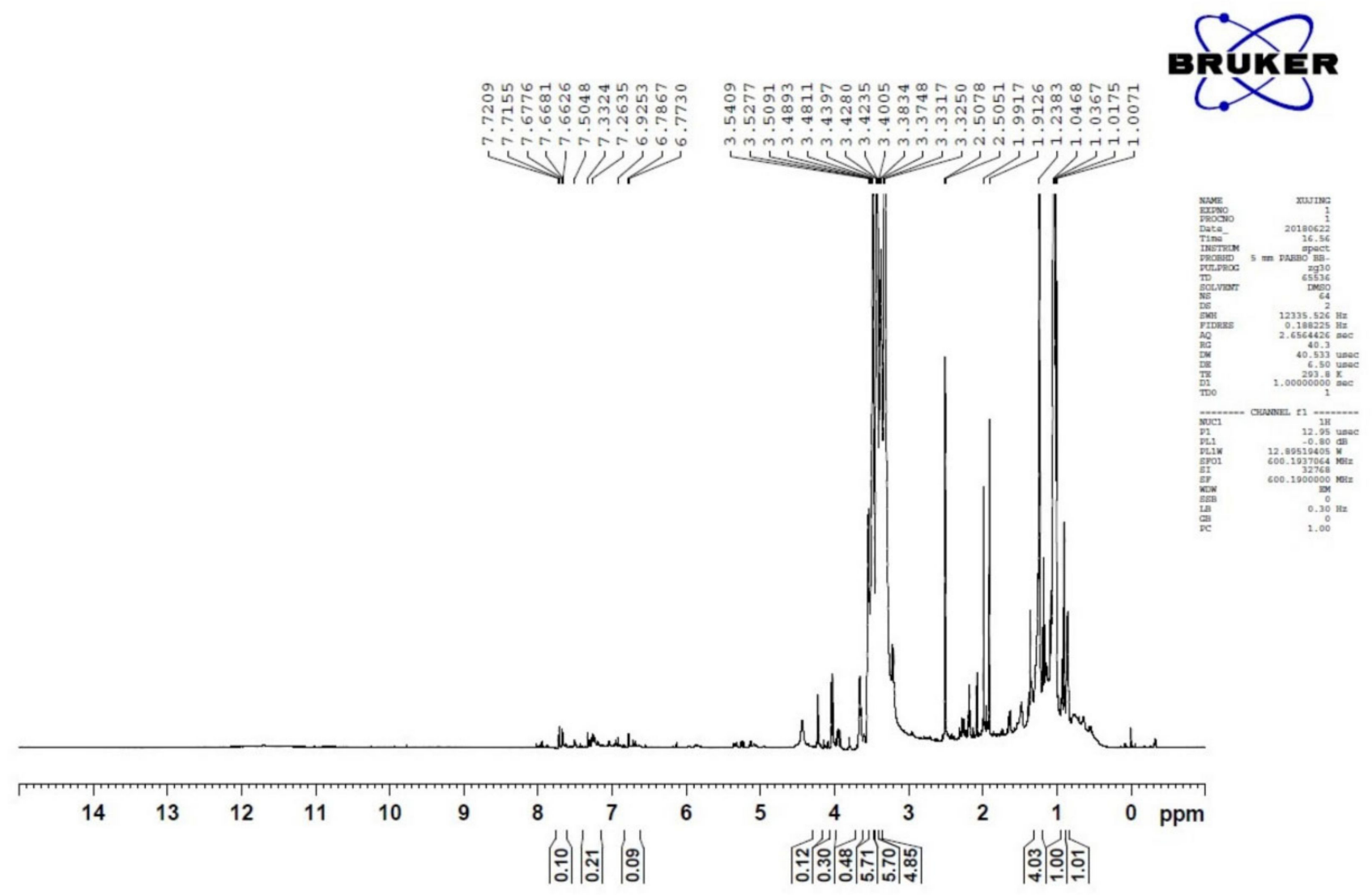

Figure 3. The ${ }^{1} \mathrm{H}$ NMR analysis of bio-active compounds produced by Cordyceps fumosorosea isolate SP502.

\subsection{HPLC Analysis}

The HPLC analysis of $C$. fumosorosea mycelial extracts and Beauvericin standard showed a similar chromatographic peak (at retention time 14.572 and $14.592 \mathrm{~min}$ ). The content of Beauvericin in crude toxin was calculated to be $0.66 \mathrm{mg} / \mathrm{mL}$ (Figure 4). 

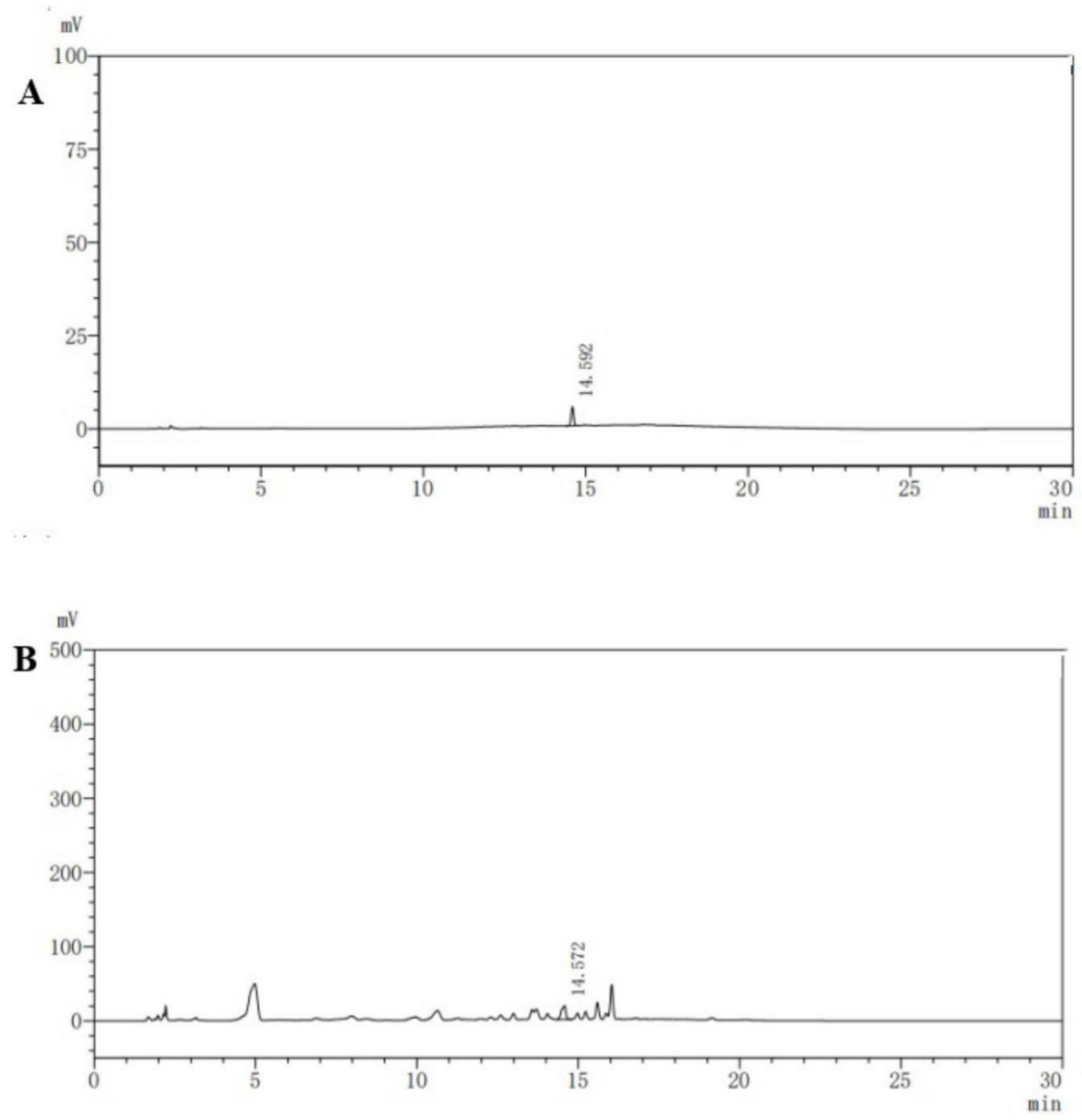

Figure 4. (A) The HPLC chromatogram of Beauvericin standard and (B) the HPLC chromatogram of mycelial extracts obtained from Cordyceps fumosorosea.

2.5. Toxicity of C. fumosorosea Secondary Metabolites Against Immature Instars of B. tabaci and A. craccivora

The insecticidal activity of ethyl acetate mycelial extracts from $C$. fumosorosea was tested against different nymphal instar stages of $B$. tabaci and A. craccivora under laboratory conditions. The mycelial extracts were toxic against first to fourth instar nymphs of $A$. craccivora after 3 days of exposure with $\mathrm{LC}_{50}$ values of $46.35,54.55,68.94$, and $81.92 \mu \mathrm{g} / \mathrm{mL}$ against first, second, third and fourth instar nymphs, respectively (Table 3).

The bioactive compounds produced by $C$. fumosorosea were also toxic against first to fourth instar nymphs of $B$. tabaci after 3 days of exposure with $\mathrm{LC}_{50}$ values of $62.67,72.84$, 77.40, and $94.40 \mu \mathrm{g} / \mathrm{mL}$ against first, second, third and fourth instar nymphs, respectively (Table 4). 
Table 3. Insecticidal activity of bioactive compounds produced by Cordyceps fumosorosea isolate SP502 against Aphis craccivora nymphs.

\begin{tabular}{|c|c|c|c|c|c|}
\hline Nymphal Instar & $\begin{array}{c}\text { Concentration } \\
(\mathrm{mg} / \mathrm{L})\end{array}$ & Mortality (\%) & $\begin{array}{c}\mathrm{LC}_{50}(\mathrm{LCL}-\mathrm{UCL}) \\
(\mathrm{mg} / \mathrm{L})\end{array}$ & $\begin{array}{c}\mathrm{LC}_{90}(\mathrm{LCL}-\mathrm{UCL}) \\
(\mathrm{mg} / \mathrm{L})\end{array}$ & $\chi^{2}(\mathrm{df}) 4$ \\
\hline \multirow{9}{*}{ 1st instar } & $\mathrm{ddH}_{2} \mathrm{O}$ & 3.27 & \multirow{9}{*}{$\begin{array}{c}46.35 \\
(30.89-66.65)\end{array}$} & \multirow{9}{*}{$\begin{array}{c}346.83 \\
(203.44-865.38)\end{array}$} & \multirow{9}{*}{24.29} \\
\hline & Ethyl acetate & 3.67 & & & \\
\hline & Matrine & 51.16 & & & \\
\hline & 10 & 14.29 & & & \\
\hline & 20 & 36.67 & & & \\
\hline & 50 & 51.67 & & & \\
\hline & 100 & 62.97 & & & \\
\hline & 200 & 78.99 & & & \\
\hline & 500 & 97.84 & & & \\
\hline \multirow{9}{*}{ 2nd instar } & $\mathrm{ddH}_{2} \mathrm{O}$ & 2.34 & \multirow{9}{*}{$\begin{array}{c}54.55 \\
(42.11-69.94)\end{array}$} & \multirow{9}{*}{$\begin{array}{c}419.39 \\
(280.43-747.78)\end{array}$} & \multirow{9}{*}{11.28} \\
\hline & Ethyl acetate & 3.33 & & & \\
\hline & Matrine & 52.34 & & & \\
\hline & 10 & 12.91 & & & \\
\hline & 20 & 31.06 & & & \\
\hline & 50 & 48.21 & & & \\
\hline & 100 & 60.37 & & & \\
\hline & 200 & 77.04 & & & \\
\hline & 500 & 94.67 & & & \\
\hline \multirow{9}{*}{ 3rd instar } & $\mathrm{ddH}_{2} \mathrm{O}$ & 2.33 & \multirow{9}{*}{$\begin{array}{c}68.94 \\
(56.14-84.77)\end{array}$} & \multirow{9}{*}{$\begin{array}{c}539.42 \\
(377.61-873.66)\end{array}$} & \multirow{9}{*}{7.55} \\
\hline & Ethyl acetate & 3.19 & & & \\
\hline & Matrine & 48.67 & & & \\
\hline & 10 & 10.97 & & & \\
\hline & 20 & 24.67 & & & \\
\hline & 50 & 41.87 & & & \\
\hline & 100 & 58.09 & & & \\
\hline & 200 & 70.33 & & & \\
\hline & 500 & 92.33 & & & \\
\hline \multirow{9}{*}{ 4th instar } & $\mathrm{ddH}_{2} \mathrm{O}$ & 2.11 & \multirow{9}{*}{$\begin{array}{c}81.92 \\
(73.47-91.52)\end{array}$} & \multirow{9}{*}{$\begin{array}{c}714.74 \\
(575.59-921.65)\end{array}$} & \multirow{9}{*}{3.46} \\
\hline & Ethyl acetate & 3.56 & & & \\
\hline & Matrine & 47.92 & & & \\
\hline & 10 & 10.02 & & & \\
\hline & 20 & 23.17 & & & \\
\hline & 50 & 37.92 & & & \\
\hline & 100 & 54.08 & & & \\
\hline & 200 & 68.23 & & & \\
\hline & 500 & 87.67 & & & \\
\hline
\end{tabular}


Table 4. Insecticidal activity of bioactive compounds produced by Cordyceps fumosorosea isolate SP502 against Bemisia tabaci nymphs.

\begin{tabular}{|c|c|c|c|c|c|}
\hline Nymphal Instar & $\begin{array}{c}\text { Concentration } \\
(\mathrm{mg} / \mathrm{L})\end{array}$ & Mortality (\%) & $\begin{array}{c}\mathrm{LC}_{50}(\mathrm{LCL}-\mathrm{UCL}) \\
(\mathrm{mg} / \mathrm{L})\end{array}$ & $\begin{array}{c}\mathrm{LC}_{90}(\mathrm{LCL}-\mathrm{UCL}) \\
(\mathrm{mg} / \mathrm{L})\end{array}$ & $\chi^{2}(\mathrm{df}) 4$ \\
\hline \multirow{9}{*}{ 1st instar } & $\mathrm{ddH}_{2} \mathrm{O}$ & 2.01 & \multirow{9}{*}{$\begin{array}{c}62.67 \\
(39.26-100.48)\end{array}$} & \multirow{9}{*}{$\begin{array}{c}339.31 \\
(185.15-1129.67)\end{array}$} & \multirow{9}{*}{9.26} \\
\hline & Ethyl acetate & 3.16 & & & \\
\hline & Matrine & 54.23 & & & \\
\hline & 10 & 13.06 & & & \\
\hline & 20 & 21.23 & & & \\
\hline & 50 & 38.54 & & & \\
\hline & 100 & 53.67 & & & \\
\hline & 200 & 82.33 & & & \\
\hline & 500 & 100 & & & \\
\hline \multirow{9}{*}{ 2nd instar } & $\mathrm{ddH}_{2} \mathrm{O}$ & 1.06 & \multirow{9}{*}{$\begin{array}{c}72.84 \\
(58.88-90.51)\end{array}$} & \multirow{9}{*}{$\begin{array}{c}442.00 \\
(311.92-712.57)\end{array}$} & \multirow{9}{*}{4.06} \\
\hline & Ethyl acetate & 2.14 & & & \\
\hline & Matrine & 53.18 & & & \\
\hline & 10 & 12.18 & & & \\
\hline & 20 & 19.36 & & & \\
\hline & 50 & 35.87 & & & \\
\hline & 100 & 51.67 & & & \\
\hline & 200 & 78.23 & & & \\
\hline & 500 & 95.08 & & & \\
\hline \multirow{9}{*}{ 3rd instar } & $\mathrm{ddH}_{2} \mathrm{O}$ & 1.37 & \multirow{9}{*}{$\begin{array}{c}77.40 \\
(61.89-97.56)\end{array}$} & \multirow{9}{*}{$\begin{array}{c}535.70 \\
(365.12-913.75)\end{array}$} & \multirow{9}{*}{4.52} \\
\hline & Ethyl acetate & 2.23 & & & \\
\hline & Matrine & 46.72 & & & \\
\hline & 10 & 11.5 & & & \\
\hline & 20 & 18.29 & & & \\
\hline & 50 & 33.33 & & & \\
\hline & 100 & 51.33 & & & \\
\hline & 200 & 75.67 & & & \\
\hline & 500 & 94.33 & & & \\
\hline \multirow{9}{*}{ 4th instar } & $\mathrm{ddH}_{2} \mathrm{O}$ & 1.24 & \multirow{9}{*}{$\begin{array}{c}94.40 \\
(75.48-119.81)\end{array}$} & \multirow{9}{*}{$\begin{array}{c}653.27 \\
(439.06-1139.34)\end{array}$} & \multirow{9}{*}{2.31} \\
\hline & Ethyl acetate & 2.87 & & & \\
\hline & Matrine & 45.91 & & & \\
\hline & 10 & 10.6 & & & \\
\hline & 20 & 15.06 & & & \\
\hline & 50 & 29.33 & & & \\
\hline & 100 & 48.16 & & & \\
\hline & 200 & 72.34 & & & \\
\hline & 500 & 89.17 & & & \\
\hline
\end{tabular}

\section{Discussion}

Cordyceps fumosorosea (previously Isaria fumosorosea) is a well-documented entomopathogenic fungus that has been widely commercialised for whitefly control [17]. This fungal species is also known to produce different insecticidal mycotoxins [25,27]. This study reports the characterization of mycelial extracts produced by $C$. fumosorosea-SP502 and their toxicity against nymphal instars of $B$. tabaci and $A$. craccivora.

FTIR analysis of the ethyl acetate mycelium extract showed the presence of prominent bands due to the $\mathrm{O}-\mathrm{H}$ stretch alcohols or phenols, $\mathrm{N}-\mathrm{H}$ alkane (Methyl), C-H alkane (Methylene), $\mathrm{C} \equiv \mathrm{C}$ stretch nitrile, $\mathrm{C}=\mathrm{O}$ carboxylic acid, $\mathrm{C}=\mathrm{C}$ stretch alkane, $\mathrm{C}=\mathrm{O}$ trans-alkenes, $\mathrm{C}=\mathrm{C}$ trans- alkenes, $\mathrm{C}=\mathrm{C}$ trans-alkenes, $\mathrm{C}=\mathrm{C}$ ester carbonyl group, $\mathrm{C}=\mathrm{C}$ ether/alcohol, $\mathrm{C}-\mathrm{O}$ trans-alkenes, $\mathrm{C}=\mathrm{C}$ vinyl-alkenes, $\mathrm{C}=\mathrm{C}$ aromatics, and aromatics (Ring). Similar functional types have also been observed by Ragavendran et al. [28] and Vivekanandhan et al. [29] in the FTIR profiles of the entomopathogenic fungus, Beauveria bassiana. The LC-MS analysis results revealed the presence of five major compounds responsible for the toxic activity of mycelial extracts, namely Trichodermin, 5-Methylmellein, Brevianamide F, Enniatin and 
Beauvericin. Previously, Qasim et al. [25] reported the production of 17 different mycotoxins, including Beauvericin by C. fumosorosea isolate FAFU-1. Supothina et al. [30] also showed Beauvericin production by Cordyceps tenuipes. The ${ }^{1} \mathrm{H}$ NMR analysis of metabolic compounds produced by C. fumosorosea isolate SP502 shows a high resonance band at the region for aliphatic, allylic, pyrrolidine ring and $\mathrm{NeCH}$, an ether linkage, and amide proton. These results are similar to the ${ }^{1} \mathrm{H}$ NMR spectra of $C$. tenuipes [30] and Metarhizium anisopliae [31]. The HPLC analysis of mycelial extracts was compared with the Beauvercin standard and they showed similar chromatographic peaks. These results are in agreement with Supothina et al. [30], who also observed Beauvericin in mycelial extracts of Cordyceps tenuipes.

In the present study, mycelial extracts of $C$. fumosorosea-SP502 were found to be toxic against different nymphal stages of both $B$. tabaci and A. craccivora. The results clearly suggested that mycelial extracts of $C$. fumosorosea-SP502 had a broad spectrum of nymphal mortality against $B$. tabaci and $A$. craccivora. These metabolites cause infection by destroying the insect cuticle layer, which can lead to their death [28]. Similar studies have also been conducted by Wang et al. [32] using mycelial extracts of another Hypocereales fungus, Akanthomyces muscarium (previously Lecanicillium muscarium), as an insecticidal agent against $B$. tabaci. They reported $\mathrm{LC}_{50}$ values of 111 and $216 \mathrm{mg} / \mathrm{L}$ for mycelial extracts of Akanthomyces muscarium V3450 and Akanthomyces muscarium Vp28, respectively against third instar nymphs of B. tabaci.

\section{Conclusions}

Our findings reveal promising results regarding the insecticidal potential of toxic compounds produced by C. fumosorosea isolate SP502 against B. tabaci and A. craccivora. The mycelial extracts of $C$. fumosorosea-SP502 had a broad spectrum of nymphal mortality against both pest species. The characterisation of extracts demonstrated that Beauvericin was one of the main constituents of the mycelial extracts, since it hadinsecticidal properties. These metabolites have potential to be further developed as biopesticides formulations to control whitefly and aphid pests.

\section{Materials and Methods}

\subsection{Insect Cultures}

Bemisia tabaci was reared on Solanum melongena as outlined by Wang et al. [15]. Briefly, a stock culture of whiteflies was obtained from the Engineering Research Centre of Biological Control, Ministry of Education, South China Agricultural University (SCAU), Guangzhou, China. Whiteflies were maintained on eggplants (cultured in $18.0 \mathrm{~cm}$ pots and kept in cages to avoid any premature infestation from whiteflies or other insects until use) placed in cages at $26 \pm 1{ }^{\circ} \mathrm{C}, 70 \pm 10 \%$ R.H., and a photoperiod of $12 \mathrm{~h}$ of light: $12 \mathrm{~h}$ of darkness.

Stock cultures of A. craccivora were collected from the experimental research fields of SCAU. Following collection, the insects were reared on Vigna unguiculata seedlings (6 weeks old) for five generations prior to the experiments, following the method of Ekesi et al. [33] at $26 \pm 1{ }^{\circ} \mathrm{C}, 70 \pm 10 \%$ R.H., and a photoperiod of $12 \mathrm{~h}$ of light: $12 \mathrm{~h}$ of darkness.

\subsection{Fungal Inoculum and Culture Conditions}

Cordyceps fumosorosea strain SP502 isolated from soil was used during this study. The fungal strain was cultured on Potato Dextrose Agar (PDA) plates following the method of Ali et al. [34]. The basal fungal suspension used during the current experiments was prepared by harvesting from PDA plates (10 days old culture) with $\mathrm{ddH}_{2} \mathrm{O}$ containing $0.03 \%$ Tween-80 and sieving them using filter paper (Whatman no. 2; Science Kit and Boreal Laboratories, New York, NY, USA) into sterile vials. Conidia were counted using a compound microscope and a hemocytometer $\left(0.0625 \mathrm{~m}^{2}\right.$; Fuchs-Rosenthal Merck Euro Lab, Darmstadt, Germany) at $40 \times$ magnification under a phase contrast microscope in order to calibrate a suspension of $1 \times 10^{7}$ conidia $/ \mathrm{mL}$. 
Erlenmeyer flasks $(500 \mathrm{~mL}$ ) containing $150 \mathrm{~mL}$ of sterilised culture medium (per litre) consisting of $30 \mathrm{~g}$ of glucose, $3 \mathrm{~g}$ of yeast extract, $0.39 \mathrm{~g}$ of $\mathrm{KH}_{2} \mathrm{PO}_{4}, 1.42 \mathrm{~g}$ of $\mathrm{Na}_{2} \mathrm{HPO}_{4} \cdot 12 \mathrm{H}_{2} \mathrm{O}, 0.60 \mathrm{~g}$ of $\mathrm{MgSO}_{4} \cdot 7 \mathrm{H}_{2} \mathrm{O}, 0.70 \mathrm{~g}$ of $\mathrm{NH}_{4} \mathrm{NO}_{3}$ and $1.00 \mathrm{~g}$ of $\mathrm{KCl}$ were inoculated with $5 \mathrm{~mL}$ of conidial suspension $\left(1 \times 10^{7}\right.$ conidia/mL) followed by incubation at $150 \mathrm{rpm}$ and $27^{\circ} \mathrm{C}$ for 5 days.

\subsection{Secondary Metabolite Extraction from Cordyceps fumosorosea}

Fungal cultures (following 5 days growth) were centrifuged at $10,000 \mathrm{rpm}, 4{ }^{\circ} \mathrm{C}$ for $10 \mathrm{~min}$ by using an Eppendorf 5804R centrifuge (Eppendorf, Germany) to remove the mycelium. The supernatant was further filtered through nylon filters (pore size $0.45 \mu \mathrm{m}$ ). The bio-active compounds were extracted using 1:1 ratio of ethyl acetate as solvent by sonication at room temperature for $10 \mathrm{~min}$ followed by incubation at $4{ }^{\circ} \mathrm{C}$ for $24 \mathrm{~h}$. The organic phase (pale yellow colour) was separated from the fermentation liquid and then the ethyl acetate was separated from the extracts by rotary vacuum evaporation at $45^{\circ} \mathrm{C}$. The dried extracts appearing as a brownish paste were used for further analytical studies.

\subsection{Liquid Chromatography-Mass Spectrophotometry (LC-MS) Analysis}

The LC-MS analysis was performed by using an LC-MS/MS system, consisting of a LC Agilent 1200 using a binary pump and an automatic injector, and coupled with a 3200 QTRAP ${ }^{\circledR}$ AB SCIEX equipped with a Turbo- $V^{\text {TM }}$ source (electrospray ionisation) interface. The chromatographic separation of the compounds was conducted at $24 \pm 1{ }^{\circ} \mathrm{C}$ on a reverse-phase analytical column $\mathrm{C}_{18}(3 \mu \mathrm{m}, 150 \times 2 \mathrm{~mm}$ ID) and a guard-column $\mathrm{C}_{18}(4 \times 2 \mathrm{~mm}$, ID; $3 \mu \mathrm{m})$. Mobile phases were as follows: methanol $(0.1 \%$ acetic acid and $5 \mathrm{mM}$ ammonium acetate) as Phase $\mathrm{A}$ and water $(0.1 \%$ acetic acid and $5 \mathrm{mM}$ ammonium acetate) as Phase B. The following gradient was used: equilibration at $90 \%$ B for 2 min, from $80 \%$ to $20 \% \mathrm{~B}$ in $3 \mathrm{~min}, 20 \%$ B for $1 \mathrm{~min}$, from $20 \%$ to $10 \% \mathrm{~B}$ in $2 \mathrm{~min}, 10 \% \mathrm{~B}$ for $6 \mathrm{~min}$, from $10 \%$ to $0 \% \mathrm{~B}$ in $3 \mathrm{~min}, 100 \%$ A for $1 \mathrm{~min}$, from $100 \%$ to $50 \%$ A in $3 \mathrm{~min}$, return to initial conditions in $2 \mathrm{~min}$, and maintain at initial conditions for $2 \mathrm{~min}$. The flow rate was $0.25 \mathrm{~mL}$ $\mathrm{min}^{-1}$ in all steps. Total run time was $21 \mathrm{~min}$. The injection volume was $20 \mu \mathrm{L}$. In regard to mycotoxin analysis, the QTRAP System was used as selected reaction monitoring (SRM). The Turbo- $\mathrm{V}^{\mathrm{TM}}$ source was used in positive mode with the following settings for source/gas parameters: curtain gas (CUR) 20, ion spray voltage (IS) 5500, source temperature (TEM) $450{ }^{\circ} \mathrm{C}$, ion source gas 1 (GS1), and ion source gas 2 (GS2) 50. The entrance potential (EP) was the same for all analytes, i.e., $10 \mathrm{~V}$. Acquisition and processing data were performed using Analyst ${ }^{\circledR}$ software, version 1.5.2 (AB SCIEX, Concord, ON, Canada).

\subsection{Fourier Transformed Infrared Spectroscopy (FTIR)}

Fourier transformed infrared spectroscopy analysis was performed by using an MIR8035 FTIR spectrometer (Thermo Fisher, Darmstadt, Germany). All measurements were made at a resolution of $4 \mathrm{~cm}^{-1}$ over a frequency range of 400 to $4000 \mathrm{~cm}^{-1}$. The liquid sample was loaded directly, and the spectra were recorded at room temperature.

\subsection{Nuclear Magnetic Resonance (NMR)}

Nuclear magnetic resonance (NMR) was performed using a Bruker advance IIIHD 600 NMR spectrometer (Bruker, Karlsruhe, Germany) by following the method of Wang et al. [32].

\subsection{High Performance Liquid Chromatography (HPLC) Analysis}

The crude extracts and pure Beauvericin were diluted in isopropanol and subjected to high performance liquid chromatography by using a LC-20AD HPLC system (Shimadzu Chromatographic Instruments, Kyoto, Japan) and an Ultimate XB-C18 column $(4.6 \times 150 \mathrm{~mm}$, and $5 \mu \mathrm{m})$ at $35^{\circ} \mathrm{C}$. Acetonitrile was employed as the mobile phase at a flow rate of $1.0 \mathrm{~mL} / \mathrm{min}$. The injection volume was $5 \mu \mathrm{L}$. The compound peaks were 
detected at $220 \mathrm{~nm}$ wavelength. Beauvericin was used as the standard. The amount of specific compound that resembles the standard was expressed as $\mathrm{mg} / \mathrm{mL}$.

5.8. Toxicity of C. fumosorosea Secondary Metabolites against Immature Instars of B. tabaci and A. craccivora

Different concentrations of fungal extracts $(500,200,100,50,20$ and $10 \mu \mathrm{g} / \mathrm{mL})$ were prepared by adding the extracts to ethyl acetate. Eggplant leaves infested with individual B. tabaci nymphal instar stages (first, second, third or fourth instar) were dipped in each concentration for $30 \mathrm{~s}$ following the methods of Cuthbertson et al. [35,36], respectively. The leaves were then air dried and placed in Petri dishes $(\varnothing 9 \mathrm{~cm})$ with moist filter paper for moisture maintenance. Bemisia tabaci nymphs dipped in Matrine $(15 \mathrm{mg} / \mathrm{L})$ acted as positive control while whitefly nymphs dipped in $\mathrm{ddH}_{2} \mathrm{O}$ served as negative control. Four eggplant leaves with $100 \mathrm{~B}$. tabaci nymphs of each instar stage/leaf were used in each treatment. The whole experimental setup was maintained at $25 \pm 1{ }^{\circ} \mathrm{C}$ and $80 \pm 5 \%$ R.H and 16:8 $\mathrm{h}$ (Light/Dark photoperiod). The whole experiment was performed three times (with a fresh batch of insects each time). Insect mortality was observed on a daily basis until 3 days post treatment.

Following the same method from Cuthbertson et al. [36], cowpea (V. unguiculata) leaves were dipped in different concentrations of fungal extracts $(500,200,100,50,20$ and $10 \mu \mathrm{g} / \mathrm{mL})$ for $30 \mathrm{~s}$. Cowpea leaves dipped in Matrine ( $15 \mathrm{mg} / \mathrm{L})$ acted as a positive control while leaves dipped in $\mathrm{ddH}_{2} \mathrm{O}$ served as a negative control. The leaves were air dried and placed in Petri dishes $(\varnothing 9 \mathrm{~cm})$ with a moist filter paper for moisture maintenance. Fifty newly moulted bean aphids up to $12 \mathrm{~h}$ old (first instar) were released on the treated and control leaf respectively in a Petri dish. The whole experimental setup was maintained at $25 \pm 1{ }^{\circ} \mathrm{C}$ and $80 \pm 5 \%$ R.H and 16:8 h (Light/Dark photoperiod). The whole experiment was performed three times (with a fresh batch of insects each time).

\subsection{Data Analysis}

Mortality (\%) was calculated and corrected with control mortality using Abbott's formula [37]. $\mathrm{LC}_{50}$ and $\mathrm{LC}_{90}$ values were calculated by probit analysis. All statistical analyses were performed using SAS 8.01 [38].

Author Contributions: Conceptualization, J.W. and S.A.; methodology, S.A.; formal analysis, J.X.; investigation, J.X. and B.Y.; resources, J.W.; data curation, J.X. and B.Y.; writing-original draft S.A.; writing-review and editing, A.G.S.C.; supervision, S.A.; funding acquisition, J.W. and S.A. All authors have read and agreed to the published version of the manuscript.

Funding: This research was funded by grants from The Key Area Research and Development Program of Guangdong Province (2018B020205003) and The Science and Technology Program of Guangzhou, P.R. China (201807010019,201804020070).

Institutional Review Board Statement: Not applicable.

Informed Consent Statement: Not applicable.

Data Availability Statement: The raw data supporting the conclusion will be made available by the corresponding author on request.

Acknowledgments: The authors want to thank the handling editor and anonymous reviewers for their constructive comments and suggestions.

Conflicts of Interest: The authors declare no conflict of interest.

\section{References}

1. Hu, J.; De Barro, P.; Zhao, H.; Wang, J.; Nardi, F.; Liu, S.S. An extensive field survey combined with a phylogenetic analysis reveals rapid and widespread invasion of two alien whiteflies in China. PLoS ONE. 2011, 6, e16061. [CrossRef] [PubMed]

2. Firdaus, S.; Vosman, B.; Hidayati, N.; Supena, E.; Darmo, J.; Visser, R.G.F.; van Heusden, A.W. The Bemisia tabaci species complex: Additions from different parts of the world. Insect Sci. 2013, 20, 723-733. [CrossRef] 
3. Cuthbertson, A.G.S.; Vänninen, I. The importance of maintaining protected zone status against Bemisia tabaci. Insects 2015, 6, 432-441. [CrossRef] [PubMed]

4. Zhang, C.; Ali, S.; Musa, P.D.; Wang, X.M.; Qiu, B.L. Evaluation of the pathogenecity of Aschersonia aleyrodis on Bemisia tabaci in the laboratory and greenhouse. Biocontrol Sci. Technol. 2017, 27, 210-221. [CrossRef]

5. Perring, T.M. The Bemisia tabaci species complex. Crop Prot. 2001, 20, 725-737. [CrossRef]

6. Stansly, P.A.; Naranjo, S.E. Bemisia: Bionomics and Management of a Global Pest; Springer: New York, NY, USA, 2010.

7. Obopile, M.; Ositile, B. Life table and population parameters of cowpea aphid, Aphis craccivora Koch (Homoptera: Aphididae) on five cowpea Vigna unguiculata (L. Walp.) varieties. J. Pest Sci. 2010, 83, 9-14. [CrossRef]

8. Tang, L.D.; Wu, J.H.; Ali, S.; Ren, S.X. The influence of different aphid prey species on biology and life table parameters of Propylea japonica. Biocontrol Sci. Technol. 2013, 23, 624-636. [CrossRef]

9. Obopile, M. Economic threshold and injury levels for control of cowpea aphid, Aphis craccivora Linnaeus (Homoptera: Aphididae) on cowpea. Afr. Plant Prot. 2006, 12, 111-115.

10. Ofuya, T.I. Control of the cowpea aphid, Aphis craccivora Koch (Homoptera: Aphididae) in cowpea, Vigna unguiculata (L.) Walp. Integr. Pest Manag. Rev. 1997, 2, 199-207. [CrossRef]

11. Cuthbertson, A.G.S.; Murchie, A.K. European red spider mite-An environmental consequence of persistent chemical pesticide application. Int. J. Environ. Sci. Technol. 2005, 2, 287-290. [CrossRef]

12. He, S.; Wu, X.Y.; Zheng, J.Z.; Han, Z.Q.; Zhao, C.X.; Wang, Y.Y.; Chen, H.; Chen, C.; Han, J. A study of control effect of Bemisia tabaci (Gennadius) on greenhouse tomatoes using parasitoid Encarsia formosa Gahan. J. Anhui Agri. Sci. 2013, 41, 6244-6248. (In Chinese)

13. Cuthbertson, A.G.S. Unnecessary pesticide applications in Northern Ireland apple orchards due to mis-identification of a beneficial mite species. Res. J. Chem. Environ. 2004, 8, 77-78.

14. Cuthbertson, A.G.S.; Murchie, A.K. The environmental impact of an orchard winter wash and early season pesticide applications on both a beneficial and a pest mite species in Bramley apple orchards. Int. J. Environ. Sci. Technol. 2006, 3, 333-339. [CrossRef]

15. Wang, X.S.; Xu, J.; Wang, X.M.; Qiu, B.L.; Cuthbertson, A.G.S.; Du, C.L.; Wu, J.H.; Ali, S. Isaria fumosorosea-based-zero-valent iron nanoparticles affect the growth and survival of sweet potato whitefly, Bemisia tabaci (Gennadius). Pest Manag. Sci. 2019, 75, 2174-2181. [CrossRef] [PubMed]

16. Du, C.L.; Yang, B.; Wu, J.H.; Ali, S. Identification and virulence characterization of two Akanthomyces attenuatus isolates against Megalurothrips usitatus (Thysanoptera: Thripidae). Insects 2019, 10, 168. [CrossRef]

17. Du, C.L.; Wu, J.H.; Cuthbertson, A.G.S.; Bashir, M.H.; Sun, T.F.; Ali, S. Morphological, molecular and virulence characterisation of six Cordyceps spp. isolates infecting the diamondback moth, Pluttela xylostella. Biocontrol Sci. Technol. 2020. [CrossRef]

18. Ali, S.; Huang, Z.; Ren, S.X. Production of cuticle degrading enzymes by Isaria fumosorosea and their evaluation as a biocontrol agent against diamondback moth. J. Pest. Sci. 2010, 83, 361-370. [CrossRef]

19. Huang, Z.; Ali, S.; Ren, S.X.; Wu, J.H. The effect of Isaria fumosorosea on mortality and fecundity of Bemisia tabaci and Plutella xylostella. Insect Sci. 2010, 17, 140-148. [CrossRef]

20. Pick, D.A.; Avery, P.B.; Hunter, W.B.; Powell, C.A.; Arthurs, S.P. Effect of Isaria fumosorosea (Hypocreales: Cordycipitaceae) and Lysiphlebus testaceipes, (Hymenoptera: Braconidae) on the brown citrus aphid: Preliminary assessment of a compatibility study. Fla. Entomol. 2012, 95, 764-766. [CrossRef]

21. Cuthbertson, A.G.S.; Audsley, N. Further screening of entomopathogenic fungi and nematodes as control agents for Drosophila suzukii. Insects 2016, 24, 7020024. [CrossRef]

22. Bernardini, M.; Carilli, A.; Pacioini, G.; Santurbano, B. Isolation of beauvericin from Paecilomyces fumosoroseus. Phytochem. Rep. 1975, 14, 1865. [CrossRef]

23. Grove, J.F.; Pople, M. The insecticidal activity of beauvericin and the enniatin complex. Mycopathologia 1980, 70, 103-105. [CrossRef]

24. Weng, Q.; Zhang, X.; Chen, W.; Hu, Q. Secondary metabolites and the risks of Isaria fumosorosea and Isaria farinosa. Molecules 2019, 24, 664. [CrossRef]

25. Qasim, M.; Islam, S.U.; Islam, W.; Noman, A.; Khan, K.A.; Hafeez, M.; Hussain, D.; Das, C.K.; Bamisisle, B.S.; Akutse, K.S.; et al. Characterization of mycotoxins from entomopathogenic fungi (Cordyceps fumosorosea) and their toxic effects to the development of asian citrus psyllid reared on healthy and diseased citrus plants. Toxicon 2020, 188, 39-47. [CrossRef] [PubMed]

26. Xu, J. Studies on the Extraction, Characterization and Toxicity of Toxins Produced by Different Isolates of Entomopathogenic Fungus Isaria fumosorosea. Master's Thesis, South China Agricultural University, Guangzhou, China, 2018.

27. Gupta, S.; Montllor, C.; Hwang, Y.S. Isolation of novel beauvericin analogues from the fungus Beauveria bassiana. J. Natl. Prod. 1995, 58, 733-738. [CrossRef]

28. Ragavendran, C.; Dubey, N.K.; Natarajan, D. Beauveria bassina (Clavicipitaceae): A potent fungal agent for controlling mosquito vectors of Anopheles stephensi, Culex quinquefasciatus and Aedes aegypti (Diptera: Culicidae). RSC Adv. 2017, 7, 3838-3851. [CrossRef]

29. Vivekanandhan, P.; Kavitha, T.; Karthi, S.; Senthil-Nathan, S.; Shivakumar, M.S. Toxicity of Beauveria bassiana-28 mycelial extracts on larvae of Culex quinquefasciatus mosquito (Diptera: Culicidae). Int. J. Environ. Res. Public Health 2018, 15, 440. [CrossRef]

30. Supothina, S.; Srisanoh, U.; Nithithanaslip, S.; Tasanathai, K.; Luangsa-ard, J.J.; Li, C.R.; Isaka, M. Beauvericin production by the lepidoptera pathogenic fungus Isaria tenuipes: Analysis of natural specimens, synnemata from cultivation, and mycelia from liquid-media fermentation. Nat. Prod. Bioprospect. 2011, 1, 112-115. [CrossRef] 
31. Ravindran, K.; Akutse, K.S.; Sivaramakrishnan, S.; Wang, L. Determination and characterization of destruxin production in Metarhizium anisopliae Tk6 and formulations for Aedes aegypti mosquitoes control at the field level. Toxicon 2016, 120, 89-96. [CrossRef] [PubMed]

32. Wang, L.; Huang, J.; You, M.S.; Guan, X.; Liu, B. Toxicity and feeding deterrence of crude toxin extracts of Lecanicillium (Verticillium) lecanii (Hyphomycetes) against sweet potato whitefly. Bemisia tabaci (Homoptera: Aleyrodidae). Pest Manag. Sci. 2017, 63, 381-387.

33. Ekesi, S.; Akpa, A.D.; Onu, I.; Ogunlana, M.O. Entomopathogenicity of Beauveria bassiana and Metarhizium anisopliae to the cowpea aphid, Aphis craccivora Koch (Homoptera: Aphididae). Arch. Phytopathol. Plant Prot. 2000, 33, 171-180. [CrossRef]

34. Ali, S.; Huang, Z.; Ren, S.X. Media composition influences on growth, enzyme activity and virulence of the entomopathogen hyphomycete Isaria fumosorosea. Entomol. Experiment. Appl. 2009, 131, 30-38. [CrossRef]

35. Cuthbertson, A.G.S.; Walters, K.F.A.; Northing, P. Susceptibility of Bemisia tabaci immature stages to the entomopathogenic fungus Lecanicillium muscarium on tomato and verbena foliage. Mycopathologia 2005, 159, 23-29. [CrossRef]

36. Cuthbertson, A.G.S.; Blackburn, L.F.; Northing, P.; Luo, W.; Cannon, R.J.C.; Walters, K.F.A. Leaf dipping as an environmental screening measure to test chemical efficacy against Bemisia tabaci on poinsettia plants. Int. J. Environ. Sci. Technol. 2009, 6, 347-352. [CrossRef]

37. Abbott, W.S. A method of computing the effectiveness of an insecticide. J. Am. Mosq. Control Assoc. 1987, 3, 302-303. [CrossRef] [PubMed]

38. SAS Institute. SAS User's Guide; Statistics SAS Institute: Cary, NC, USA, 2000. 